\title{
The effect of feeding Gliricidia Leaf Meal (GLM) on the haematological, serological and carcass characteristics of weaned rabbits in the tropics
}

\author{
Amata, I. A \\ Department of animal science and fisheries, Delta state university, asaba campus, \\ Asaba, Nigeria
}

\begin{abstract}
In an experiment to determine the effect of feeding graded levels of Gliricidia sepium Leaf Meal (GLM) on the heamatology, serum chemistry and carcass characteristics of rabbits in the tropics, twenty-five (25) weaned rabbits of mixed sexes, 5-6 weeks old, were randomly allotted to five (5) dietary treatments in which GLM replaced soybean meal (SBM) at $0 \%$ (control), $5 \%, 10 \%$, $15 \%$ and $20 \%$ with five (5) rabbits per treatment in a completely randomised design. Each rabbit constituted a replicate. Haematological and serological parameters measured at the end of 8 weeks of feeding indicated significant $(P<0.05)$ variations in packed cell volume $(P C V)$, mean cell haemoglobin $(\mathrm{MCH})$ and serum albumins, and highly significant $(P<0.01)$ changes in erythrocyte counts (RBC), leucocytes counts (WBC) and in total serum proteins with variations in the level of dietary GLM. The haemoglobin ( $\mathrm{Hb})$, mean cell volume (MCV) mean cell haemoglobin concentration $(\mathrm{MCHC})$ and serum globulins were, however, unaffected $(P>0.05)$ by variations in the level of dietary GLM.
\end{abstract}

Keywords: Gliricidia sepium leaf meals, serum albumins, mean cell volume, haemoglobin and packed cell volume.

\section{INTRODUCTION}

The search for alternative feed resources for farm animals as a way of reducing production costs, and making livestock products more readily available to the populace in the tropics is far from over (Herbert, 1998). A situation in which the average Nigerian still consumes only about $7.4 \mathrm{~g}$ of animal protein per day (FAOSTAT, 2005), which is still far below the recommended animal protein level of $35 \mathrm{~g}$ per required by an average adult human for proper health, is undesirable. It is known that some tree legumes in the tropics, notably Gliricidia sepium and Leucaena leucocephala, have attracted attention for their ability to provide large quantities of high quality forages all year round as well as their ability to maintain a sustainable environment and soil fertility through nitrogen fixation (Simons and Stewart, 1994). The use of these legumes as livestock feeds has the potential of significantly bringing down the cost of commercial livestock feeds, which are very high in Nigeria, primarily because the conventional ingredients used to supply the protein components in these feeds also serve as food for humans, and as raw materials in industries. However, studies by Akpata (1989), Aletor and Aledetimi (1989) and Ologhobo et al. (1993) have shown that the use of some legumes as protein sources could produce some undesirable physiological and biological alterations when such legumes are fed in their raw state to monogastric animals, which may be manifest in the haematological and serological qualities of the animals. Since these qualities reflect the physiological responses of animals to their health, environment and nutrition (Oyewole and Ogwegbu, 1986), values reported for rabbits in the temperate zone may not be useful in assessing the health and nutritional status of rabbits in the tropics.

This study was therefore carried out to ascertain the effect, on the haematological, serological and carcass characteristics of rabbits, of feeding diets in which soybean meal (SBM) was replaced at varying levels with Gliricidia Leaf Meal (GLM) to rabbits.

Justification of the Study: The findings of the study will generate useful information that will help reduce cost of finished feed for rabbits. Gliricidia sepium leaf meal is not used for human consumption and thus makes it readily available as animal feed, in this case it can be used for rabbit feed.

MATERIALS AND METHODS: This study was conducted in the Rabbit Unit of the Delta State University Teaching and Research Farm, Asaba Campus in Delta State Nigeria (6 $6^{\circ} 14^{\prime} \mathrm{N}$ and 6 $\left.6^{\circ} 49^{\prime} \mathrm{E}\right)$.

Test materials and diets: Fresh, young Gliricidia sepium leaves were harvested, sun-dried for several days and subsequently milled to obtain Gliricidia Leaf 
Meal (GLM) and incorporated into five rabbit diets in which soybean meal (SBM) was replaced with GLM at $0 \%$ (control), $5 \%, 10 \%, 15 \%$ and $20 \%$ respectively. The diets (Table 1) were formulated to contain approximately $17 \%$ crude protein and $2340 \mathrm{kcal} / \mathrm{kg}$ metabolizable energy. Dry samples of GLM and the experimental diets were analysed for their proximate values using standard A.O.A.C (1990) procedures.

Experimental animals: Twenty-five (25) Dutch rabbits of mixed sexes, aged 5-6 weeks, were weighed individually, and randomly assigned to the five dietary treatments with five rabbits per treatment. Each rabbit was regarded as a replicate. The rabbits were housed singly in cages in two rows of hutches. Each of the cages measured approximately $70 \mathrm{cmx}$ $60 \mathrm{~cm} \times 54 \mathrm{~cm}$. The hutches were raised approximately $80 \mathrm{~cm}$ from the concrete floor in a house with $1 \mathrm{~m}$ dwarf walls, which permitted sufficient ventilation. The rabbits were provided with the experimental diets and clean water ad libitum for 8weeks, after an initial pre-trial adjustment period of two weeks.

Data collection and analysis: At the end of the 8 week period, two (2) rabbits per treatment were chosen at random and weighed. Blood was collected into two vials from each of the rabbits through venipuncture of the left ear, using sterile lancets. One vial contained ethylene diamine tetra acetic acid (EDTA) as an anti-coagulant, and the other without the anti-coagulant for serum generation. The noncoagulated blood samples were used for the determination of packed cell volume(PCV) using the micro-hematocrit technique, the red blood cells (RBC) and the white blood cells (WBC) counts using the improved Neubauer hematocytometer method, and haemoglobin $(\mathrm{Hb})$ using the cyanomethemoglobin method (Kelly, 1979). Serum from the coagulated blood samples were used for the measurement of total protein, albumins, globulins and cholesterol. From the PCV, RBCand $\mathrm{Hb}$ values, mean corpuscular haemoglobin $(\mathrm{MCH})$, mean corpuscular haemoglobin concentration $(\mathrm{MCHC})$ and mean corpuscular volume (MCV) were computed by the method described by Jain (1986).

The rabbits were thereafter stunned, sacrificed by cervical dislocation and dissected in accordance with the World Rabbit Science Association guidelines.

The experiment was a completely randomized design (CRD), with the following model: $X_{i j}=\mu+a_{i}+i j$

Where $X_{i j}=$ any of the response variables (PCV, RBC, WBC, Hb etc). $\mu=$ the overall means

$a_{i}=$ effect of the $i$ th treatment ( $i=1,2,3,4$ and5).

$\mathrm{ij}=$ random error due to experimentation.

Data collected was analysed by the one-way analysis of variance procedure using the IRRISTAT for Windows (Version 5.0) computer software. Significantly different means were separated by the Duncan's Multiple Range Test procedure (Duncan, 1955).

\section{RESULTS and DISCUSSION}

Proximate Composition of GLM and the Experimental Diets: The results of the laboratory analysis of the experimental diets showing their energy and proximate compositions appear in the lower part of Table 1, while the proximate composition of GLM is presented in Table2. The protein contents of the diets fall within the range recommended for growing rabbits by NRC (1984). The values obtained for GLM also fell within the range of nutrients reported for Gliricidia in the tropics by Gohl (1981), Chadokar (1982) and Adejumo and Ademosun (1985). Its protein content of $15.6 \%$ was however, lower than values reported for Gliricidia sepium (18.5\% to $26.1 \%)$ by Carew (1983) while its crude fibre content was higher than that reported by Herbert 91988) due, perhaps, to differences in soil characteristics to which the plants were exposed, processing procedures and climate. Its gross energy content $(3.46 \mathrm{kcal} / \mathrm{kg})$ was similar to that reported by Mba et al. (1982), while its ash content of $11.58 \%$ compared favourably with the $11.0 \%$ reported for the plant by Reynolds and Adeoye (1986).

Haematological and Serological Characteristics: The haematological and serological characteristics of the rabbits fed the experimental diets are presented in Table 3. No significant differences $(P>0.05)$ were noticed in the $\mathrm{Hb}, \mathrm{MCV} \mathrm{MCHC}$ values, and the globulins of rabbits fed GLM-based diets and those fed the control diets. The $\mathrm{MCH}$ values varied significantly $(\mathrm{P}<0.05)$ with dietary treatments, however the $\mathrm{MCH}$ values were similar for both rabbits fed 20\% GLM and those fed the control diets. These findings indicate that Gliricidia sepium does not adversely interfere with haemoglobin formation and function. Values obtained for $\mathrm{Hb}, \mathrm{MCH}$ and $\mathrm{MCHC}$ were within the normal ranges reported for these variables by Hewet et al. (1989) for New Zealand white rabbits, Macro et al for the European brown hare and by Omoikhoje et al. the crossbreed of Chinchilla/New Zealand white rabbits. 
Table 1: Composition of the Experimental Diets (\% Dry Matter)

\begin{tabular}{|c|c|c|c|c|c|}
\hline \multirow[t]{2}{*}{ Ingredients } & \multicolumn{5}{|c|}{ Levels of GLM Inclusion (\%) } \\
\hline & 0 & 5 & 10 & 15 & 20 \\
\hline Maize & 57.33 & 57.33 & 57.33 & 57.33 & 57.33 \\
\hline Soybean Meal & 21.27 & 18.57 & 15.77 & 13.02 & 10.27 \\
\hline GLM & - & 2.75 & 5.50 & 8.25 & 11.27 \\
\hline Fishmeal & 3.00 & 3.00 & 3.00 & 3.00 & 3.00 \\
\hline Wheat offal & 15.00 & 15.00 & 15.00 & 15.00 & 15.00 \\
\hline Bone meal & 2.00 & 2.00 & 2.00 & 2.00 & 2.00 \\
\hline Oyster shell & 0.80 & 0.80 & 0.80 & 0.80 & 0.80 \\
\hline Salt & 0.40 & 0.40 & 0.40 & 0.40 & 0.40 \\
\hline Premix & 0.20 & 0.20 & 0.20 & 0.20 & 0.20 \\
\hline \multicolumn{6}{|l|}{ Proximate Composition } \\
\hline Dry matter & 92.65 & 90.60 & 89.76 & 91.80 & 93.88 \\
\hline Crude protein & 17.29 & 17.38 & 17.40 & 17.36 & 17.24 \\
\hline Crude fibre & 10.48 & 11.38 & 12.68 & 13.96 & 14.25 \\
\hline Ether extract & 3.35 & 3.60 & 3.38 & 3.12 & 3.08 \\
\hline Ash & 3.49 & 3.52 & 3.64 & 3.96 & 4.25 \\
\hline Nitrogen-free extract & 58.04 & 54.72 & 52.66 & 53. 40 & 55.06 \\
\hline Gross Energy (kcal g ${ }^{-1}$ ) & 4.26 & 4.21 & 4.08 & 3.97 & 4.10 \\
\hline
\end{tabular}

Table 2: Energy and Proximate Composition of Gliricidia Leaf Meal (GLM)

\begin{tabular}{|l|r|}
\hline Composition & \\
\hline Dry matter (\%) & 89.65 \\
\hline Crude protein (\%) & 15.60 \\
\hline Crude fibre (\%) & 13.77 \\
\hline Ether extract (\%) & 1.41 \\
\hline Ash (\%) & 11.58 \\
\hline Nitrogen-free extract (\%) & 47.29 \\
\hline Gross Energy (kcal g & ) \\
\hline
\end{tabular}

$\mathrm{PCV}, \mathrm{WBC}, \mathrm{RBC}$ values and the serological variables (albumins, globulins and total proteins) varied significantly $(P>0.05)$ with dietary treatments. The similarity of the PCV values of the $20 \%$ GLM treatment group with those of the 0\%, and 5\% GLM groups suggests that variations in percentage PCV may not have been due entirely to the treatments applied. The values of between $37.7 \%$ and $44.5 \%$, however fell within the normal range of PCV values (26.7\% - 47.2\%), Hewet et al. (1989) and 30\% -50\% for rabbits RAR (2007). Erythrocyte concentration $(R B C)$ in the blood was significantly $(P<0.05)$ depressed at dietary levels of GLM higher than $10 \%$.

Carcass Characteristics: The carcass characteristics of the rabbits as affected by dietary inclusion of GLM are presented in Table 4.Carcass characteristics were unaffected $(P>0.05)$ by variations in dietary GLM, indicating that rabbits can tolerate up to $20 \%$ dietary inclusion of GLM in their diets.

Table 3: Haematological and Serological Characteristics of Rabbits fed the Experimental Diets (Mean \pm SEM)

\begin{tabular}{|c|c|c|c|c|c|}
\hline \multirow[t]{2}{*}{ Parameters } & \multicolumn{5}{|c|}{ Levels of GLM inclusion (\%) } \\
\hline & 0 & 5 & 10 & 15 & 20 \\
\hline PCV (\%) & $44.50 \pm 5.20^{a}$ & $42.00 \pm 3.03^{\mathrm{a}}$ & $37.50 \pm 4.05^{b}$ & $38.00 \pm 6.10^{b}$ & $39.04 \pm 2.70^{\mathrm{ab}}$ \\
\hline $\operatorname{RBC}\left(10^{6} / \mathrm{ml}\right)$ & $6.40 \pm 0.07^{\mathrm{a}}$ & $6.01 \pm 0.04^{b}$ & $6.24 \pm 0.03^{\mathrm{ab}}$ & $5.46 \pm 0.08^{c}$ & $5.98 \pm 0.01^{\mathrm{bc}}$ \\
\hline WBC $\left(10^{6} / \mathrm{ml}\right)$ & $75.40 \pm 2.54^{\mathrm{b}}$ & $75.96 \pm 1.92^{b}$ & $79.43 \pm 2.11^{\mathrm{a}}$ & $68.37 \pm 2.47^{\mathrm{C}}$ & $60.49 \pm 1.99^{d}$ \\
\hline $\mathrm{Hb}(\mathrm{g} / \mathrm{dl})$ & $13.60 \pm 0.47^{a}$ & $13.60 \pm 0.29^{a}$ & $13.61 \pm 0.15^{\mathrm{a}}$ & $13.65 \pm 0.45^{a}$ & $13.67 \pm 0.76^{a}$ \\
\hline $\mathrm{MCH}(\mathrm{pg})$ & $19.80 \pm 0.34^{b}$ & $20.97 \pm 0.22^{b}$ & $20.13 \pm 0.11^{b}$ & $22.14 \pm 0.59^{a}$ & $21.35 \pm 0.55^{\mathrm{ab}}$ \\
\hline $\mathrm{MCHC}(\%)$ & $31.88 \pm 4.08^{a}$ & $32.86 \pm 3.72^{a}$ & $30.76 \pm 4.68^{a}$ & $31.96 \pm 3.18^{a}$ & $33.95 \pm 5.03^{a}$ \\
\hline $\operatorname{MCV}(\mathrm{fl})$ & $52.23 \pm 3.87^{\mathrm{a}}$ & $53.95 \pm 5.69^{\mathrm{a}}$ & $51.57 \pm 2.63^{\mathrm{a}}$ & $53.08 \pm 1.75^{\mathrm{a}}$ & $53.12 \pm 2.20^{\mathrm{a}}$ \\
\hline Albumins ( $g / L)$ & $2.84 \pm 0.02^{a}$ & $2.81 \pm 0.03^{\mathrm{ab}}$ & $2.75 \pm 0.02^{\mathrm{bc}}$ & $2.73 \pm 0.01^{\mathrm{c}}$ & $2.77 \pm 0.01^{\mathrm{bc}}$ \\
\hline Globulins (g/L) & $1.57 \pm 0.02^{a}$ & $1.57 \pm 0.05^{a}$ & $2.15 \pm 0.06^{a}$ & $1.53 \pm 0.03^{a}$ & $1.56 \pm 0.02^{a}$ \\
\hline Total Proteins ( $\mathrm{g} / \mathrm{L})$ & $10.30 \pm 0.33^{C}$ & $12.50 \pm 0.25^{\mathrm{ab}}$ & $12.70 \pm 0.22^{\mathrm{a}}$ & $11.90 \pm 0.18^{b}$ & $11.00 \pm 0.21^{\mathrm{C}}$ \\
\hline
\end{tabular}


Agric. Biol. J. N. Am., 2010, 1(5): 1057-1060

Table 4: Carcass Characteristics of Rabbits Fed the Experimental Diets (Mean \pm SEM)

\begin{tabular}{|l|l|l|l|l|l|}
\hline \multicolumn{1}{|c|}{ Parameters } & \multicolumn{5}{c|}{ Levels of GLM inclusion (\%) } \\
\hline Carcass Length (cm) & \multicolumn{1}{c|}{$\mathbf{0}$} & \multicolumn{1}{c|}{$\mathbf{5}$} & \multicolumn{1}{c|}{$\mathbf{1 0}$} & \multicolumn{1}{c|}{$\mathbf{1 5}$} & \multicolumn{1}{c|}{$\mathbf{2 0}$} \\
\hline Dressed Weight (DW) (g) & $27.20 \pm 0.50$ & $26.30 \pm 0.60$ & $28.78 \pm 0.45$ & $28.05 \pm 0.65$ & $28.95 \pm 0.55$ \\
\hline Dressing (\%) & $635.66 \pm 1.88$ & $644.39 \pm 4.43$ & $647.66 \pm 6.51$ & $671.58 \pm 6.91$ & $589.17 \pm 8.66$ \\
\hline Loin (\%DW) & $59.31 \pm 2.91$ & $54.24 \pm 5.01$ & $57.30 \pm 5.11$ & $53.45 \pm 2.71$ & $58.26 \pm 3.02$ \\
\hline Head (\%DW) & $23.19 \pm 1.69$ & $26.83 \pm 2.60$ & $29.01 \pm 2.31$ & $25.33 \pm 1.18$ & $27.21 \pm 1.28$ \\
\hline Leg (\%DW) & $7.98 \pm 0.61$ & $8.15 \pm 0.57$ & $8.61 \pm 0.17$ & $7.92 \pm 0.34$ & $9.65 \pm 0.31$ \\
\hline Rib (\%DW) & $16.34 \pm 1.07$ & $17.33 \pm 1.12$ & $17.08 \pm 2.18$ & $19.11 \pm 0.98$ & $18.43 \pm 1.26$ \\
\hline Shoulders (\%DW) & $11.76 \pm 2.13$ & $10.92 \pm 2.09$ & $15.73 \pm 2.80$ & $13.67 \pm 2.09$ & $12.44 \pm 1.18$ \\
\hline Skin (\%DW) & $14.46 \pm 3.27$ & $15.28 \pm 4.41$ & $15.73 \pm 2.80$ & $16.39 \pm 1.95$ & $16.53 \pm 2.09$ \\
\hline
\end{tabular}

levels of GLM up to $20 \%$ inclusion does not affect haematological parameters Values obtained fall within reported ranges. Dietary treatment has no effect on carcass characteristics. GLM can be included in the diets of weaner rabbits up to $20 \%$ without any adverse effects to haematological and serological parameters and carcass characteristics.

\section{REFERENCES.}

Adegbola, T, A., Tibi, E.U and Adogwa, D.C. (1985). J.Anim.Prod.Res 5(2): 15-16.

Adejumo, J.O. and Ademosun, A.A. (1985). J.Anim.Prod.Res.5:1-2.

Akinnusi, F.A.O., Bamgbose, A.M., Sogunle, O.M. and Afolabi, F.O. (2007). Proc.32 ${ }^{\text {nd }}$ Ann. Con. Nig. Soc. Anim. Prod., Calabar, Nigeria. Pp 305-306.

A.O.A.C. (1990) Official methods of analyses. Association of Official Analytical Chemists (15 ${ }^{\text {th }}$ edition) Washington D.C.

Asuquo, B.O. (1997). Nig.J.Anim.Prod.24 (1):46-50.

Attah-Krah, A.A. and Sumberg, (1986). Agro-Forestry systems 6:167-178.

Bitto, I.I., Arubi, J.A. and Gumel, A.A. (2006). Afr. J. Biomed. Res. 9: 199-204.

Carew, B.A.R. (1983). Tropical Grassland 17(4):181-183.

Chadhokar, P.A. (1982). Wild Animal review.44:36-43.

Duncan, D.B. (1955). Multiple range and F-tests. Biometrics.

FAOSTAT, (2005). FAO statistics database. Food and Agriculture Organization, Rome, Italy.

G hl, B. (1981). FAO Animal Production and Health series No. 12. FAO, Rome, Italy.

Hewlett, C.D., Innes, D.J., Savory, J. and Wills, M.R. (1989).Clin. Chem.25 (8): 1777.
Kelly, W.R. (1979). Veterinary Clinical Diagnosis. $2^{\text {nd }}$ edition, Bailliere Tindall, London.

Marco, I., Cuenca, R., Pastor, J., Velarde, R. and Lavin, S. (2003). Haematology and serum chemistry values of the European Brown Hare. Vet Clin. Pathol. 32(4): 195198.

Mba, A.U., Mangui, S.A. and Awah, A.A. (1982). The Contribution of Poultry, Swine and Rabbit Production in Warm Wet Climates. Spectrum Books Ltd., Ibadan.

NRC (1984). Nutrient Requirements of Rabbits. $2^{\text {nd }}$ edition revised, National Academies of Science Press, Washington DC.

Odeyinka, S.M. and Ijiyemi, O.C.(1997). Nig. J. Anim. Prod.24 (1): 51-53.

Omoikhoje, S.O., Bamgbose, A.M., Aruna, M.B and Animashaun, R.A. (2006).Pakistan J. of Nutr. 5(6): 577-579.

Oruseibio, S.M. (2002).A Textbook of Rabbit Production F\&F Publishers, Nigeria.

Oyewole, J.O. and Ogwegbu, S.O. (1986). Practical hints for backyard poultry producers. Livestock Management Series 1:16-28.

RAR (2007). Reference Values for Laboratory Animals: Normal Haematological Values. Research Animal Resources, University of Minnesota. http://www.ahc.umn.edu/rar/index.html.

Reynolds, L. and Adeoye, S.A.O (1986). Paper presented at the International Workshop on Alley Farming for Humid and Sub-humid Regions of Tropical Africa. IITA, Ibadan, Nigeria, 10-14 March, 1986.

Slade, L.M. and Hintz, H.F. (1969). Journal of Animal Science 28:642-643.

Sobayo, R.A., Okubanjo, O.A., Adeyemi, O.A. and Usman, J.M.(2007). Sustainability of the Livestock Industry in an Oil Economy. Proc. 32 ${ }^{\text {nd }}$ Ann. Confr.Nig.Soc. Anim. Prod. Calabar, Nigeria. pp 268-271. 